\title{
Upaya Pengobatan Sendiri pada Balita dalam Era Cakupan Semesta Jaminan Kesehatan
}

\section{Self Medication among Toddlers During Universal Health Coverage}

\author{
Eka Fitria
}

\author{
Loka Penelitian dan Pengembangan Biomedis Aceh Kementerian Kesehatan Republik Indonesia
}

\begin{abstract}
Abstrak
Upaya pengobatan sendiri merupakan perilaku individu dalam mengenali jenis penyakit yang diderita dan memilih sendiri jenis pengobatan. Kriteria yang menentukan pemilihan sumber pengobatan adalah persepsi sakit/ pengetahuan akan penyakit, keyakinan akan sumber pengobatan, dan efisiensi waktu yang dipengaruhi oleh keterjangkauan biaya dan jarak. Penelitian ini bertujuan mendeskripsikan upaya pengobatan sendiri pada balita di Aceh dalam era cakupan semesta jaminan kesehatan dan mengetahui faktor-faktor yang memengaruhinya. Penelitian ini merupakan analisis data sekunder hasil KOR-MODUL Susenas 2011 dengan pendekatan potong lintang sebanyak 43.866 responden atau 455.750 rumah tangga di 23 Kabupaten/Kota Provinsi Aceh. Terdapat 5.147 responden balita yang mewakili populasi balita Aceh, sebanyak 2.052 balita (39,87\%) dilaporkan menderita sakit selama sebulan sebelum survei, $62,52 \%$ ternyata dirawat dengan upaya pengobatan sendiri. Meskipun telah berlaku cakupan semesta jaminan kesehatan di Aceh, masih banyak balita yang diobati sendiri oleh keluarganya. Hasil analisis uji kai kuadrat dan regresi logistik menunjukkan bahwa faktor domisili, usia balita, dan diare memengaruhi upaya pengobatan sendiri pada balita.
\end{abstract}

Kata kunci: Balita, cakupan semesta jaminan kesehatan, pengobatan sendiri

\section{Abstract}

Self medication is the choice of medications by individuals to cure selfrecognized symptoms or indications. Self medication are determined by the perception/knowledge of the illness, beliefs, and efficiency as it is affected by affordability and distance to health care facility. This study aimed to describe the use of self-medication among toddler in Aceh during the era of universal health coverage, and to determine the factors that control its. This was a secondary data analysis of the results of KOR-MODUL Susenas 2011 with a cross-sectional approach as many as 43,866 respondents or 455,750 households in 23 districts/cities in Aceh province. There are 514 respon- dents representing toddler population of Aceh, and 2,052 toddler or $39.87 \%$ are sick during the last month prior to the survey and $62.52 \%$ were selfmedication. Nevertheless, some families still practice self-medication in the era of universal health coverage; in short, chi-square and logistic regression imply that living area, age of toddler, and diarrhea are determining the use of self-medication.

Keywords: Toddler, universal health coverage, self-medication

\section{Pendahuluan}

Upaya pengobatan sendiri merupakan perilaku individu dalam mengenali jenis penyakit yang diderita dan memilih sendiri jenis pengobatan, baik secara modern maupun tradisional, tanpa petunjuk ahlinya sebagai sumber pengobatan. ${ }^{1}$ Sumber pengobatan pada hakikatnya dapat dibagi dalam tiga kategori, meliputi pengobatan sendiri dengan menggunakan obat medis, obat tradisional, atau terapi tradisional; pengobatan medis melalui bantuan tenaga medis seperti perawat, bidan, atau dokter; dan pengobatan tradisional melalui bantuan herbalis atau ahli terapi tradisional. ${ }^{2}$ Kriteria yang menentukan pemilihan sumber pengobatan adalah persepsi sakit/ pengetahuan akan penyakit, keyakinan akan sumber pengobatan dan efisiensi waktu yang dipengaruhi oleh keterjangkauan biaya dan jarak. ${ }^{3}$

Alasan pemilihan upaya pengobatan sendiri secara umum adalah penyakit yang diderita tidak parah, sebagai upaya pertolongan pertama, masalah privasi, taraf ekonomi keluarga yang rendah, ketiadaan akses fasilitas ke-

Alamat korespondensi: Eka Fitria, Loka Litbang Biomedis Aceh Kemenkes RI, Jl. Sultan Iskandar Muda Blang bintang Lorong Tgk. Dilangga No. 9 Banda Aceh, Hp.08126951352,e-mail:ummu.nuh.thalhah@gmail.com 
sehatan, dan berdasarkan pengalaman terhadap penyakit yang diderita. ${ }^{4}$ Faktor-faktor sosial-ekonomi yang memengaruhi keputusan untuk melakukan upaya pengobatan sendiri khususnya melalui konsumsi obat tradisional di Indonesia adalah kelompok usia lanjut, status menikah /pernah menikah, pendidikan rendah, nelayan atau tidak bekerja dan masyarakat pedesaan. ${ }^{5}$ Pemerintah Aceh sejak Juni tahun 2010 telah memberlakukan program cakupan semesta jaminan kesehatan bagi seluruh warga Aceh yang tidak mempunyai akses terhadap segala bentuk jaminan kesehatan lainnya. ${ }^{6}$ Program cakupan semesta jaminan kesehatan tersebut telah memberikan akses yang lebih mudah dengan biaya terjangkau bahkan gratis bagi masyarakat Aceh khususnya bagi masyarakat miskin.

Susenas 2011 melibatkan sebanyak 43.866 responden di Provinsi Aceh dan menunjukkan bahwa 29,9\% penduduk Aceh mengeluh sakit dalam waktu sebulan sebelum survei. Dari total penduduk yang mengeluh sakit, $15,64 \%$ adalah balita. Dari 2.052 balita yang dilaporkan sakit dalam waktu sebulan sebelum survei, $62,52 \%$ ternyata dirawat dengan upaya pengobatan sendiri.

Penelitian bertujuan untuk mendeskripsikan upaya pengobatan sendiri pada balita di Aceh di era cakupan semesta jaminan kesehatan dan mengetahui faktor-faktor yang memengaruhinya. Manfaat penelitian yang diharapkan adalah sebagai informasi dalam penyusunan kebijakan tentang upaya pengobatan sendiri pada balita di masyarakat.

\section{Metode}

Penelitian ini merupakan analisis data sekunder hasil
KOR-MODUL Susenas Badan Pusat Statistik tahun 2011 dengan desain potong lintang pada 43.866 atau 455.750 rumah tangga di 23 Kabupaten/Kota Provinsi Aceh. Dalam data KOR Susenas 2011, terdapat 5.147 responden balita yang mewakili populasi balita Aceh, sebanyak 2.052 balita atau 39,87\% dilaporkan menderita sakit selama sebulan terakhir sebelum survei. Kemudian $62,52 \%$ atau 1.283 balita yang sakit ternyata diobati sendiri pada periode berlakunya cakupan semesta jaminan kesehatan di Provinsi Aceh.

Variabel dalam penelitian ini meliputi karakteristik rumah tangga yang terdiri dari usia kepala rumah tangga, jenis kelamin kepala rumah tangga, status kepala rumah tangga, pekerjaan kepala rumah tangga, status keluarga miskin, dan domisili kepala rumah tangga. Karakteristik balita meliputi jenis kelamin, usia, dan hubungan kekerabatan. Sedangkan, karakteristik persepsi sakit balita meliputi panas, batuk, pilek, asma, dan diare. Data dianalisis dengan uji statistik kai kuadrat dan regresi logistik.

\section{Hasil}

Hasil uji statistik memperlihatkan hubungan yang bermakna antara domisili kepala rumah tangga dengan upaya pengobatan sendiri. Hal ini dapat ditunjukkan dengan nilai $\mathrm{OR}=0,75$; nilai $\mathrm{p}=0,003 ; 95 \% \mathrm{CI}=0,62-0,90$ (Tabel 1).

Terdapat hubungan bermakna antara usia balita dengan upaya pengobatan sendiri dengan nilai $\mathrm{OR}=0,80$; nilai $\mathrm{p}=0,016 ; 95 \% \mathrm{CI}=0,67-0,96$. Hubungan kekerabatan dengan upaya pengobatan sendiri juga menunjukkan hasil yang signifikan dengan nilai $\mathrm{OR}=1,36$; ni-

Tabel 1. Hasil Uji Regresi Logistik Bivariat Karakteristik Kepala Rumah Tangga dan Kemungkinan Upaya Pengobatan Sendiri

\begin{tabular}{|c|c|c|c|c|c|c|c|c|}
\hline \multirow{3}{*}{ Variabel } & \multirow{3}{*}{ Kategori } & \multicolumn{4}{|c|}{ Upaya Pengobatan Sendiri } & \multirow{3}{*}{ OR } & \multirow{3}{*}{ 95\% CI } & \multirow{3}{*}{ Nilai $p$} \\
\hline & & \multicolumn{2}{|l|}{ Ya } & \multicolumn{2}{|c|}{ Tidak } & & & \\
\hline & & $\mathbf{n}$ & $\%$ & $\mathbf{n}$ & $\%$ & & & \\
\hline \multirow[t]{4}{*}{ Usia (tahun) } & $18-24$ & 13 & 1,01 & 7 & 0,91 & 1,00 & & \\
\hline & $25-35$ & 177 & 13,80 & 128 & 16,64 & 1,34 & $0,521-3,461$ & 0,541 \\
\hline & $35-56$ & 754 & 58,77 & 435 & 56,57 & 1,07 & $0,424-2,706$ & 0,884 \\
\hline & $>56$ & 339 & 26,42 & 199 & 25,88 & 1,09 & $0,428-2,778$ & 0,856 \\
\hline \multirow[t]{2}{*}{ Jenis kelamin } & Pria & 998 & 77,79 & 611 & 79,45 & 1,00 & & \\
\hline & Wanita & 285 & 22,21 & 158 & 20,55 & 0,91 & $0,728-1,127$ & 0,374 \\
\hline \multirow[t]{2}{*}{ Status pernikahan } & Menikah & 999 & 77,86 & 607 & 78,93 & 1,00 & & \\
\hline & Cerai & 284 & 22,14 & 162 & 21,07 & 0,94 & $0,755-1,167$ & 0,57 \\
\hline \multirow[t]{6}{*}{ Pekerjaan } & Berusaha sendiri & 336 & 26,19 & 185 & 24,06 & 1,00 & & \\
\hline & Dibantu buruh tidak dibayar & 294 & 22,92 & 196 & 25,49 & 1,21 & $0,939-1,562$ & 0,141 \\
\hline & Dibantu buruh yang diupah & 64 & 4,99 & 39 & 5,07 & 1,11 & $0,715-1,713$ & 0,649 \\
\hline & Buruh/karyawan/pegawai & 319 & 24,86 & 190 & 24,71 & 1,08 & $0,839-1,394$ & 0,544 \\
\hline & Pekerja bebas & 83 & 6,47 & 55 & 7,15 & 1,20 & $0,819-1,769$ & 0,346 \\
\hline & Pekerja keluarga/tidak dibayar & 5 & 0,39 & 4 & 0,52 & 1,45 & $0,385-5,477$ & 0,581 \\
\hline \multirow[t]{2}{*}{ Status keluarga miskin } & Ya & 1.087 & 84,72 & 646 & 84,01 & 1,00 & & \\
\hline & Tidak & 196 & 15,28 & 123 & 15,99 & 1,06 & $0,826-1,350$ & 0,664 \\
\hline \multirow[t]{2}{*}{ Domisili } & Desa & 775 & 60,41 & 254 & 33,03 & 1,00 & & \\
\hline & Kota & 508 & 39,59 & 515 & 66,97 & 0,75 & $0,624-0,908$ & 0,003 \\
\hline
\end{tabular}


Tabel 2. Hasil Uji Regresi Logistik Bivariat Karakteristik Balita dan Kemungkinan Upaya Pengobatan Sendiri

\begin{tabular}{|c|c|c|c|c|c|c|c|c|}
\hline \multirow{3}{*}{ Variabel } & \multirow{3}{*}{ Kategori } & \multicolumn{4}{|c|}{ Upaya Pengobatan Sendiri } & \multirow{3}{*}{ OR } & \multirow{3}{*}{$95 \%$ CI } & \multirow{3}{*}{ Nilai $p$} \\
\hline & & \multicolumn{2}{|c|}{ Ya } & \multicolumn{2}{|c|}{ Tidak } & & & \\
\hline & & $\mathbf{n}$ & $\%$ & $\mathbf{n}$ & $\%$ & & & \\
\hline \multirow{2}{*}{ Jenis kelamin } & Pria & 639 & 49,81 & 394 & 51,24 & 1,00 & & \\
\hline & Wanita & 644 & 50,19 & 375 & 48,76 & 0,94 & $0,790-1,129$ & 0,531 \\
\hline \multirow[t]{2}{*}{ Usia (bulan) } & $0-24$ & 585 & 45,60 & 393 & 51,11 & 1,00 & & \\
\hline & $36-59$ & 698 & 54,40 & 376 & 48,89 & 0,80 & $0,670-0,960$ & 0,016 \\
\hline \multirow[t]{2}{*}{ Hubungan kekerabatan } & Anak & 1.181 & 92,05 & 688 & 89,47 & 1,00 & & \\
\hline & Cucu/anak asuh & 102 & 7,95 & 81 & 10,53 & 1,36 & $1,003-1,852$ & 0,048 \\
\hline
\end{tabular}

Tabel 3. Hasil Uji Regresi Logistik Bivariat Persepsi Penyakit yang Diderita Balita dan Hubungannya dengan Kemungkinan Upaya Pengobatan Sendiri

\begin{tabular}{|c|c|c|c|c|c|c|c|c|}
\hline \multirow{3}{*}{ Variabel } & \multirow{3}{*}{ Kategori } & \multicolumn{4}{|c|}{ Upaya Pengobatan Sendiri } & \multirow{3}{*}{ OR } & \multirow{3}{*}{ 95\% CI } & \multirow{3}{*}{ Nilai $p$} \\
\hline & & \multicolumn{2}{|c|}{ Ya } & \multicolumn{2}{|c|}{ Tidak } & & & \\
\hline & & n & $\%$ & $\mathbf{n}$ & $\%$ & & & \\
\hline \multirow[t]{2}{*}{ Panas/demam } & Tidak & 348 & 27,12 & 180 & 23,41 & 1,00 & Reference & \\
\hline & Ya & 935 & 72,88 & 589 & 76,59 & 1,22 & $0,990-1,499$ & 0,062 \\
\hline \multirow[t]{2}{*}{ Batuk } & Tidak & 456 & 35,54 & 376 & 48,89 & 1,00 & Reference & \\
\hline & Ya & 827 & 64,46 & 499 & 64,89 & 1,02 & $0,845-1,229$ & 0,843 \\
\hline \multirow[t]{2}{*}{ Pilek } & Tidak & 440 & 34,29 & 285 & 37,06 & 1,00 & Reference & \\
\hline & Ya & 843 & 65,71 & 484 & 62,94 & 0,89 & $0,736-1,07$ & 0,205 \\
\hline \multirow[t]{2}{*}{ Asma/sesak napas } & Tidak & 1,256 & 97,90 & 762 & 99,09 & 1,00 & Reference & \\
\hline & Ya & 27 & 2,10 & 7 & 0,91 & 0,43 & $0,185-0,986$ & 0,046 \\
\hline \multirow[t]{2}{*}{ Diare } & Tidak & 1,167 & 90,96 & 720 & 93,63 & 1,00 & Reference & \\
\hline & Ya & 116 & 9,04 & 49 & 6,37 & 0,68 & $0,484-0,968$ & 0,032 \\
\hline
\end{tabular}

Tabel 4. Hasil Uji Regresi Logistik Multivariat Variabel Bebas yang Bermakna terhadap Upaya Pengobatan Sendiri

\begin{tabular}{|c|c|c|c|c|c|c|c|c|}
\hline \multirow{3}{*}{ Variabel } & \multirow{3}{*}{ Kategori } & \multicolumn{4}{|c|}{ Upaya Pengobatan Sendiri } & \multirow{3}{*}{ OR } & \multirow{3}{*}{$95 \% \mathrm{CI}$} & \multirow{3}{*}{ Nilai $p$} \\
\hline & & \multicolumn{2}{|c|}{ Ya } & \multicolumn{2}{|c|}{ Tidak } & & & \\
\hline & & $\mathbf{n}$ & $\%$ & $\mathbf{n}$ & $\%$ & & & \\
\hline \multirow[t]{2}{*}{ Domisili } & Desa & 775 & 60,41 & 254 & 33,03 & 1,00 & Reference & \\
\hline & Kota & 508 & 39,59 & 515 & 66,97 & 0,76 & $0.627-0,914$ & 0,004 \\
\hline \multirow[t]{2}{*}{ Usia (bulan) } & $0-24$ & 585 & 45,60 & 393 & 51,11 & 1,00 & Reference & \\
\hline & $36-59$ & 698 & 54,40 & 376 & 48,89 & 0,78 & $0.656-0.940$ & 0,009 \\
\hline \multirow[t]{2}{*}{ Diare } & Tidak & 1,167 & 90,96 & 720 & 93,63 & 1,00 & Reference & \\
\hline & Ya & 116 & 9,04 & 49 & 6,37 & 0,69 & $0,487-0,980$ & 0,038 \\
\hline
\end{tabular}

lai $\mathrm{p}=0,048 ; 95 \% \mathrm{CI}=1,00-1,85($ Tabel 2$)$.

Hubungan bermakna didapatkan antara asma/sesak napas dengan upaya pengobatan sendiri dengan adanya nilai $\mathrm{OR}=\mathrm{O}, 43$; nilai $\mathrm{p}=0,046 ; 95 \% \mathrm{CI}=0,18-0,98$. Demikian pula dengan diare dan upaya pengobatan sendiri juga menunjukkan hubungan bermakna dengan nilai $\mathrm{OR}=\mathrm{O}, 68$; nilai $\mathrm{p}=0,03 ; 95 \% \mathrm{CI}=0,48-0,96$ (Tabel $3)$.

Dari hasil uji regresi logistik bivariat didapatkan bahwa di antara 14 variabel bebas yang diduga berpengaruh pada upaya pengobatan sendiri pada balita, diperoleh hubungan yang bermakna pada lima variabel, yaitu domisili, usia balita, hubungan kekerabatan, asma/sesak napas, dan diare. Variabel-variabel yang mempunyai hubungan bermakna dianalisis lebih lanjut melalui uji regresi logistik multivariat sebagai model akhir. Kemudian, diperoleh tiga variabel bebas yang paling bermakna secara berturut-turut, yaitu domisili, usia balita, dan diare dengan nilai $\mathrm{p}<0,05$ (Tabel 4).

\section{Pembahasan}

Pada hasil data Susenas tahun 2011, tercatat $62,52 \%$ atau 1.283 balita yang sakit ternyata diobati sendiri pada periode ketika telah berlakunya cakupan semesta jamin- 
an kesehatan di Provinsi Aceh. Hasil penelitian juga membuktikan ternyata terdapat beberapa faktor yang sangat memengaruhi pengobatan sendiri pada balita di Aceh. Salah satunya adalah domisili, yaitu akses dari tempat tinggal menuju ke sarana pelayanan kesehatan yang jauh membuat orangtua memilih untuk melakukan pengobatan sendiri terhadap balitanya yang sakit.

Dari hasil penelitian diperoleh hubungan bermakna antara domisili kepala rumah tangga dengan upaya pengobatan sendiri pada balita. Uji bivariat menunjukkan bahwa rumah tangga di pedesaan mempunyai kemungkinan 1,33 kali lebih besar untuk melakukan pengobatan sendiri pada balita dibandingkan dengan rumah tangga di perkotaan. Penelitian Mardiana, ${ }^{7}$ juga menyatakan bahwa apabila dalam keluarga ada anggotanya yang sakit panas, hal tersebut dianggap sebagai malaria dan tindakan pertama yang dilakukan sebagian besar warga di Desa Buaran dan Desa Geneng, Kabupataen Jepara, Jawa Tengah adalah mengobati sendiri penyakitnya dan sebagian kecil membawa ke sarana pelayanan kesehatan. Masyarakat yang berdomisili di perkotaan lebih kecil melakukan pengobatan sendiri pada balita, hal ini disebabkan oleh akses pelayanan kesehatan di perkotaan lebih mudah dijangkau oleh masyarakat setempat.

Hasil penelitian mendapatkan hubungan bermakna antara usia balita dengan upaya pengobatan sendiri. Balita pada usia 0 hingga 24 bulan mempunyai kemungkinan 1,25 kali lebih besar untuk dilakukan upaya pengobatan sendiri dibandingkan dengan balita pada usia 36 hingga 59 bulan. Hubungan kekerabatan dalam keluarga juga memengaruhi upaya pengobatan sendiri. Balita dengan hubungan kekerabatan sebagai cucu/anak asuh mempunyai kemungkinan 1,36 kali lebih besar untuk dilakukan upaya pengobatan sendiri jika dibandingkan dengan anak kandung.

Balita dengan persepsi sakit asma/sesak napas berpengaruh terhadap upaya pengobatan sendiri. Persepsi sakit selain asma mempunyai kemungkinan diupayakan pengobatan sendiri, pada balita 2,32 kali lebih besar jika dibandingkan dengan sakit asma. Contohnya pada penderita diare, dalam menanggulangi penyakit diare di Indonesia, pemerintah melalui kebijakannya ikut memberdayakan rumah tangga untuk penatalaksanaan penderita diare dengan cara yang tepat dan benar seperti pemberian oralit, air putih yang dimasak, air tajin, dan kuah yang berasal dari sayur. ${ }^{8}$ Persepsi sakit diare juga mempunyai pengaruh terhadap upaya pengobatan sendiri pada balita. Balita dengan persepsi sakit selain diare mempunyai kemungkinan hampir 1,5 kali lebih besar untuk dilakukan pengobatan sendiri jika dibandingkan dengan persepsi sakit diare. Teori Dolinsky dalam Supardi dan Notosiswoyo, ${ }^{9}$ mengatakan bahwa persepsi seseorang terhadap sakit dapat berbeda sehingga dapat memengaruhi keputusan yang akan diambil. Interpretasi yang berbeda terhadap sakit yang diderita juga menyebabkan pemilihan sumber pengobatan yang berbeda.

\section{Kesimpulan}

Meskipun telah berlaku cakupan semesta jaminan kesehatan di Provinsi Aceh, namun masih banyak balita yang diobati sendiri oleh keluarganya. Dari hasil analisis multivariat, diperoleh bahwa faktor domisili, usia balita dan diare memengaruhi upaya pengobatan sendiri pada balita.

\section{Saran}

Dari hasil penelitian ini, domisili kepala rumah tangga menjadi faktor yang paling berpengaruh dengan upaya pengobatan sendiri pada balita. Rumah tangga di perdesaan lebih tinggi melakukan upaya pengobatan sendiri sehingga disarankan apabila pengobatan dilakukan sendiri dalam rumah tangga maka harus diperhatikan jenis penyakit yang diderita, begitu juga obat-obatan yang diberikan harus sesuai dengan aturan pakai dan efek samping yang ditimbulkannya. Harapan kepada pemerintah adalah untuk terus dapat memberikan informasi melalui upaya penyuluhan kesehatan secara berkesinambungan kepada masyarakat dalam hal ini ikut memberdayakan keluarga sehingga mereka dapat meningkatkan pengetahuan dan terampil dalam mengobati penyakit yang dapat dilakukan dalam tingkat rumah tangga.

\section{Ucapan Terima Kasih}

Penulis mengucapkan terima kasih kepada Kepala Loka Litbang Biomedis Aceh atas semangat dan nasihatnya, kepala Badan Pusat Statistik Aceh yang telah memberikan raw data Susenas, keluarga atas segala doa dan dukungan, dan ersemua pihak atas bantuannya.

\section{Daftar Pustaka}

1. Jain S, MalviR, Purviya, Jeetendra K. Concept of self medication. International Journal of Pharmaceutical \& Biological Archives. 2011; 2 (3): 831-6.

2. Young JC. Medical choice in a Mexican Village, New Brunswick. NJ: Ritgers University Press; 1981.

3. Young JC. A Model of illness treatment decisions in a Tarascan Town. American Ethnologist. 1980; 7: 106-131.

4. Jaina P, Sachanb A, Singla RK, Agrawa P. Statistical studyon self medication pattern in Haryana, India. Indo Global Journal of Pharmaceutical Sciences. 2012; 2 (1): 21-35.

5. Supardi S, Suyanty AL. Penggunaan obat tradisional dalam upaya pengobatan sendiri di Indonesia (analisis data Susenas 2007). Buletin Penelitian Kesehatan. 2010; 38 (2): 80-9.

6. Ramadhan I, Thabrany H. The impact of universal health coverage associated with socio economical and medical factors on neonatal mortality in Aceh-Indonesia, 2012. The 4th International Conference on Aceh and Indian Ocean Studies 2013. Lhokseumawe, North Aceh, Indonesia. 8-10 June 2013. Lhokseumawe: ICAIOS; 2013. 
Fitria, Upaya Pengobatan Sendiri pada Balita

7. Mardiana, Santoso SS. Peran serta masyarakat dalam upaya penanggulangan malaria di Desa Buaran dan Desa Geneng, Kabupaten Jepara, Jawa Tengah. Media Penelitian dan Pengembangan Kesehatan. Maret 2004; 14(1): 15-21.

8. Kementerian Kesehatan Republik Indonesia. Situasi diare di Indonesia.
Buletin Jendela Data dan Informasi Kesehatan. 2011; 2 (2): 19.

9. Supardi S, Notosiswoyo M. Pengobatan sendiri sakit kepala, demam, batuk dan pilek pada masyarakat di Desa Ciwalen, Kecamatan Warung Kondang, Kabupaten Cianjur, Jawa Barat. Majalah Ilmu Kefarmasian. Agustus 2005; 2(3): 134-44. 